\title{
Localization and Anatomical Identification of Theta and Complex Spike Cells in Dorsal Hippocampal Formation of Rats
}

\author{
S. E. Fox And J. B. Ranck, JR. ${ }^{1}$ \\ Department of Physiology, Unizersity of Michigan, Ann. Arbor, Michigan 48104
}

Receired April 13

\begin{abstract}
Microelectrodes were passed through the dorsal hippocampal formation of unrestrained rats, recording for at least $5 \mathrm{~min}$ each $35.3 \mu \mathrm{m}$. At each site the amplitude and duration of action potential spikes, frequency of firing, relation to slow wave theta rhythm, and presence of complex spikes or theta cells was recorded. One thousand and fourteen neurons were recorded from. (When recording from many neurons simultaneously, the "number" of the neurons was "counted" in an arbitrary and approximate way.) Of 949 nontheta cells greater than $80 \mu \mathrm{V}$ amplitude, only one was not in the hilus of fascia dentata or in a layer of cells which overlapped stratum pyramidale and stratum granulosum. These are the locations of the cell bodies of projection cells (pyramidal cells and granule cells). However, this layer is, up to $400 \mu \mathrm{m}$ thicker than stratum pyramidale. Theta cells were seen in sites of cell bodies of projection cells and also in stratum oriens of CA1, suprapyramidal layers of CA3, and dorsal part of the hilus of fascia dentata. The frequency of occurrence in these locations corresponded to the distribution of cell bodies of interneurons. We conclude that the class of projection cells and the class of nontheta cells have a very large uverlap, and that the class of interneurons and the class of theta cells have a very large overlap.
\end{abstract}

\section{INTRODUCTION}

In an earlier study it was shown that there are at least two distinct groups of neurons in dorsal Ammon's horn and fascia dentata of unre-

1 Current address for both authors is: Dept. of Physiology, Downstate Medical Center, State University of New York, Brooklyn, New York 11203. Sally Wu and Jacqueline Smith helped in some of the early stages of the work. The technical assistance of Ann Maxwell was important throughout. This work was supported by grants from the National Institute of Mental Health ( $M H$ 12979), The National Science Foundation (GB 26184), and the National Institute of Health (NS-10970). 
strained rats: theta cells and complex spike cells (10). A complex spike cell is any neuron which fires "complex spikes," even though this may be a rare event. A complex spike is a series of 2 to 11 spikes with 1.6 to $6 \mathrm{msec}$ interspike intervals, in which the amplitude of the extracellularly recorded spike changes during the series, usually decreasing. Theta cells never fire complex spikes. Most of the time theta cells fire faster than $5 / \mathrm{sec}$, while complex spike cells usually fire less than $12 / \mathrm{sec}$. (Most are less than $2 / \mathrm{sec}$.) The duration of the extracellularly recorded action potential is shorter in theta cells than in complex spike cells. Theta cells increase their rate of firing if, and only if, there is a regular slow wave theta rhythm present in the hippocampus-hence their name. Firing of complex spike cells has no simple relation to the presence or absence of a slow wave theta rhythm.

In this early study it was noted that complex spike cells were in the vicinity of stratum pyramidale or stratum granulosum. Theta cells were recorded from these and other sites. The purpose of this present study was to localize accurately these two types of cells and to determine any anatomical classifications which coincided with this electrophysiological classification. In the earlier study it was suggested that theta cells might be interneurons, and complex spike cells might be pyramidal cells and granule cells. Let us group pyramidal and granule cells together and call them "projection cells." By interneurons we mean nonprojection cells, which are also neurons with axons less than $1 \mathrm{~mm}$ long.

From this study we conclude that the class of interneurons and the class of theta cells have a very large overlap. The class of complex spike cells and the class of pyramidal cells also have a very large overlap. The data for granule cells are not as good, but a similar relation is suggestcd. Except where otherwise noted, all anatomical statements are from Lorente de Nó (6).

\section{METHODS}

The methods have been described in detail previously $(9,10)$. Briefly, action potentials and slow waves were recorded with a moveable tungsten or stainless steel microelectrode, etched to a point, and insulated to within $10 \mu \mathrm{m}$ of the tip. Other hippocampal slow waves and neocortical EEG were recorded from fixed $125 \mu \mathrm{m}$ electrodes. The rats were male SpragueDawley weighing $350-450 \mathrm{~g}$. At least 1 week elapsed after surgery before recording. The amplifier for recording action potentials had a flat frequency response between 1000 and $5000 \mathrm{~Hz}$, falling off $8.6 \mathrm{db}$ /octave below $500 \mathrm{~Hz}$.

A microelectrode was lowered through dorsal hippocampal formationfirst on one side, and on another day, on the other side. Once in hippocampal formation the electrode was moved at $35.3 \mu \mathrm{m}$ increments $(0.1$ turn 
of a 1-72 screw). The electrode was left in place for at least $5 \mathrm{~min}$ at each site. If any action potentials were seen, the amplitude and duration of negativity, approximate frequency of firing, firing pattern, and relation of firing to presence or absence of slow wave theta rhythm, or to the behavior associated with this rhythm was measured and written down.

At the time of recording, neurons were classified into "complex spike cells," "theta cells," "slow cells," and "other cells." Theta cells and complex spike cells were identified by criteria previously published (10). Slow cells were cells which met all the criteria of complex spike cells, except that a complex spike was never seen. As shown previously, a complex spike may be a rare event, and some neurons fired in this mode only while the rat was in slow wave sleep. We observed these cells for 5 min or a little longer, and many cells were not observed while the rat was in slow wave sleep. Surely some of these slow cells were complex spike cells. However, others may not have been (cf. 8). In the earlier study a cell was called a complex spike cell, even if a complex spike was not seen, if the cell met all the other criteria for a complex spike cell and the cell was not observed while the rat was in slow wave sleep. Stronger criteria are used in the present study. The "other" category includes all cells that do not unequivocally fit into the first three categories. All action potentials seen were classified into one of these groups.

In the layer of complex spike cells, action potentials from many neurons were recorded at each site. Sometimes isolation of action potentials from one or two single neurons was possible. Even in these cases there were always other smaller action potentials which could not be clearly isolated from one another. We "counted" action potentials by separating out amplitudes which differed by more than $20 \%$ or $20 \mu \mathrm{V}$, whichever was greater. Individual theta cells could always be separated from other cells. There was always some level below which action potentials could not be unequivocally separated from noise. This level was higher in the layer of complex spike cells than elsewhere. The level also varied with use of different electrodes. It was always $50-100 \mu \mathrm{V}$.

Small electrolytic lesions (5-15 $\mu \mathrm{A}$, anodal current, 5-15 sec) were made at the end of the recording track to determine the histological identification of recording sites. In two tracks in fascia dentata, stainless steel microelectrodes were used so that the prussian biue reaction could be used for more precise localization of recording site.

Animals were perfused with $10 \%$ formalin in saline, brains were removed, and $40 \mu \mathrm{m}$ frozen sections were stained with cresyl violet for localization of the electrode tracks. In animals where the prussian blue reaction was used, formalin perfusion was followed by perfusion with freshly prepared saturated potassium ferrocyanide in $10 \%$ formalin. 


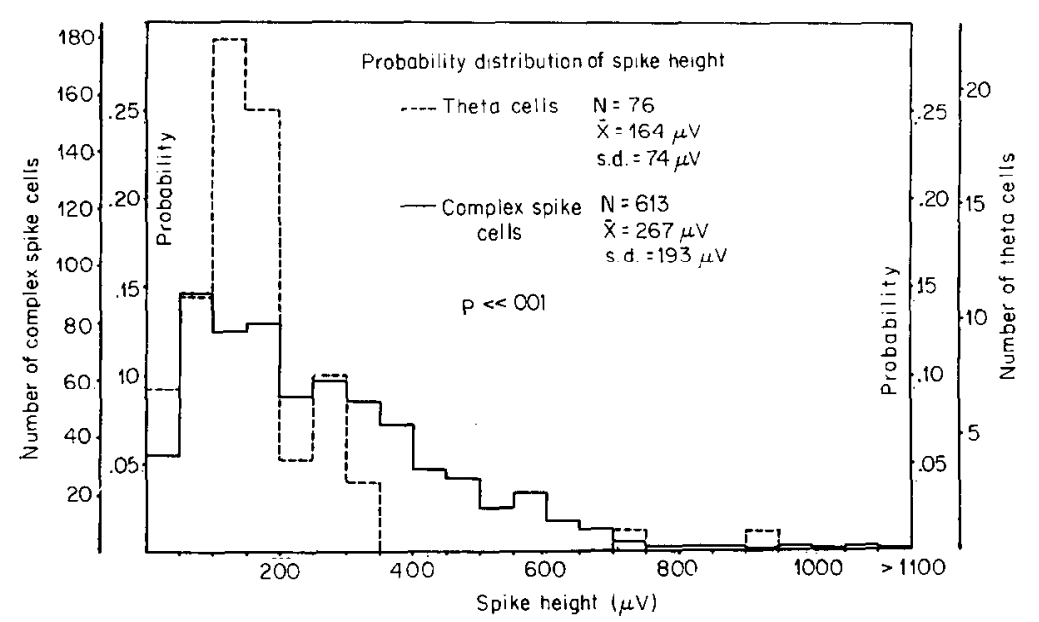

FIg. 1. Probability distributions of spike heights: Theta cells vs. complex spike cells. The abscissa consists of spike height bins of $50 \mu \mathrm{v}$ width (spike height $=$ extracellular negativity, baseline to peak). The left ordinate shows probability and numbers of complex spike cells in the complex spike cell bins; the right, probability and number of theta cells in the theta cell bins. The total area under each curve equals 1 . The probability that both curves are samples from the same population is much less than 0.001 by the Mann-Whitney $U$ Test.

\section{RESULTS}

Spike height distribution of theta cells and complex spike cells differed significantly. Fig. 1 shows the distribution of spike heights (extracellular negativity measured from the baseline to peak of the action potential). In the case of complex spike cells, the height of single action potentials or of the first spike in a burst was recorded. (These were always the same.) The mean amplitude of action potentials of complex spike cells was $267 \mu \mathrm{V}$. The action potentials of theta cells were usually less than $200 \mu \mathrm{V}$ in amplitude and almost always less than $300 \mu \mathrm{V}(\overline{\mathrm{X}}=164 \mu \mathrm{V})$. The MannWhitney $U$ test showed the probability that these two distributions were taken from the same population to be much less than 0.001 .

In Ammon's horn, theta cells were $6-7 \%$ of recordable cells, whereas complex spike cells made up about $60 \%$ of that population (Table 1 ). In the fascia dentata area the data were not so good for reasons given below, but there were more theta cells (mostly inside the hilus), fewer complex spike cells, and more slow cells. There were more complex spike cells and fewer slow cells in CA3 as compared with other areas. The complex spike mode of firing is evidently more common in CA3. Sixty-nine percent of the "other" cells were recorded in the first part of the experiment. With more experience the frequency of identification of this category decreased. 


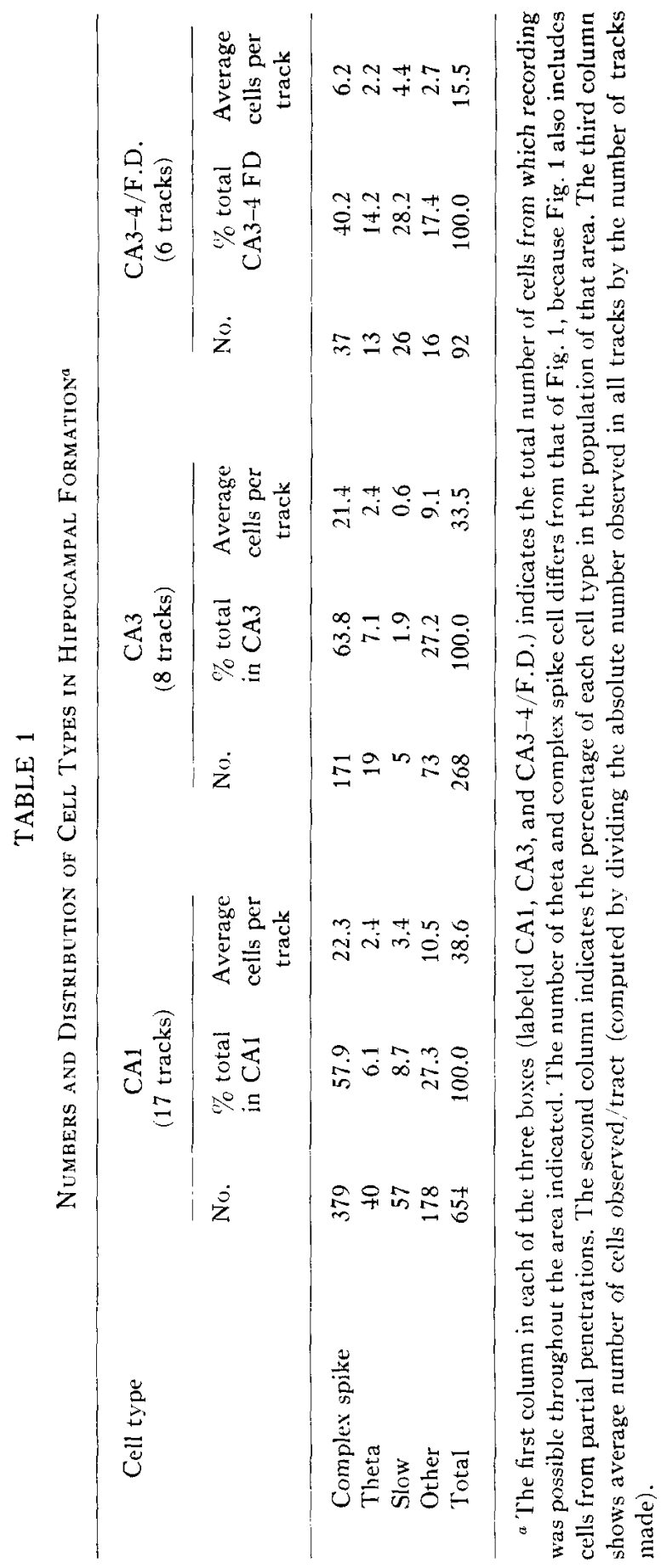



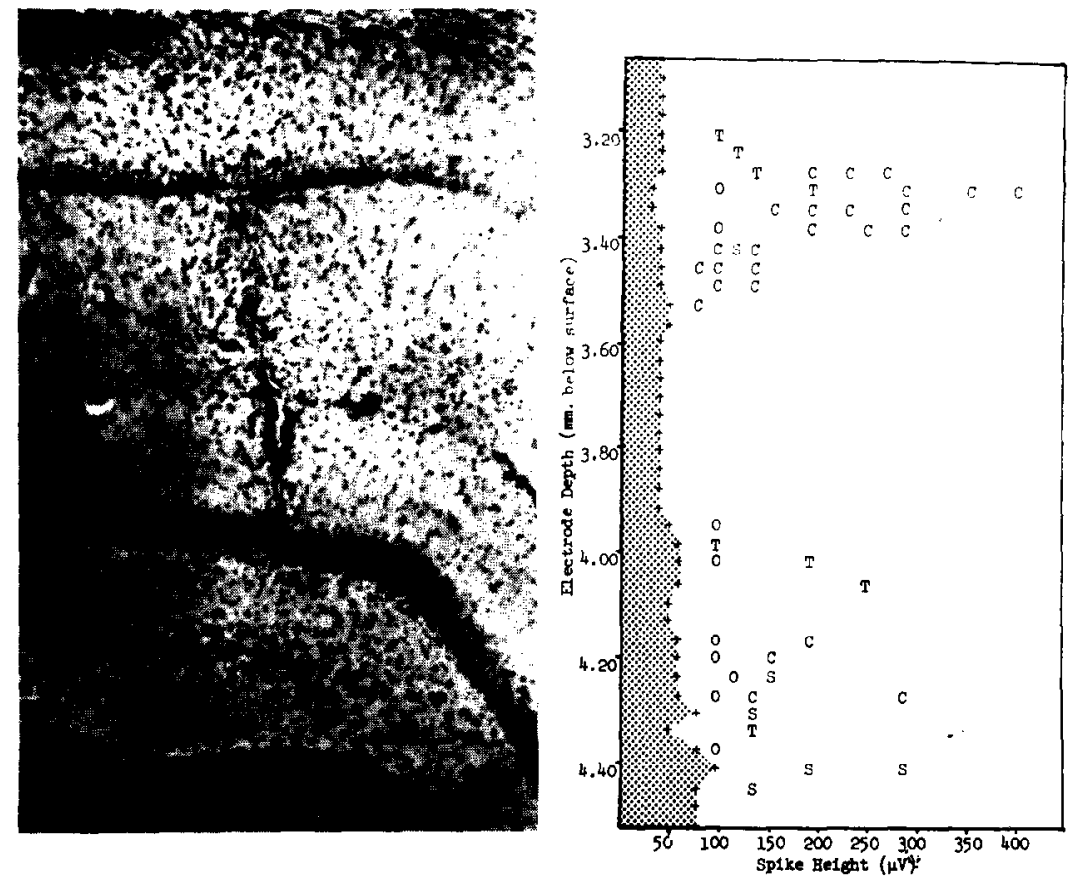

Fig. 2. Cell types seen at various hippocampal levels. Right half: Electrode depth below surface versus spike height (microvolts extracellular negativity-filtered). C, Complex Spike Cell; T, Theta Cell; S, Slow Cell; O, Others. Shaded area is noise level or level below which no isolation could be obtained. Left half: Nissl stained frozen section $(40 \mu \mathrm{m})$ showing portion of electrode track to which the data on right corresponds.

Some special difficulties were encountered in recording from fascia dentata. Electrophysiologically, the hilar border of the layer of complex spike cells was much less clear than the border on molecular layer and sometimes it was not clear at all. We could not always distinguish the granule cell layer of fascia dentata from the polymorph layer, CA4, and the intrahilar part of CA3. Therefore we grouped these together in Table 1. In another study a track was made through the granule cell layer without recording any action potentials. In a track of still another study, the electrode was left at a site where no action potentials were present initially, only to have action potentials appear after $5 \mathrm{~min}$. A microlesion showed this site to be in granule cell layer of fascia dentata. Many neurons in fascia dentata fired much more slowly than neurons in Ammon's horn. Fewer neurons were recorded in a single track in fascia dentata than elsewhere in hippocampal formation in spite of the dense packing of neurons. These data suggest that granule cells are more readily damaged than pyramidal cells, or that many granule cells do not fire at all for minutes and are 
missed. In any event, neuron counts from fascia dentata have more error than counts in Ammon's horn. (Counting errors are discussed more completely in the discussion.)

In a track through Ammon's horn there was always a clear layer of nontheta cells, near the site where stratum pyramidale was expected (Fig. 2). Two $20 \mu \mathrm{m}$ lesions were made at the dorsal border of this electrophysiological layer in CA1, and one $20 \mu \mathrm{m}$ lesion was made on the ventral border. In all cases the lesion was within $50 \mu \mathrm{m}$ of the corresponding border of stratum pyramidale. However, the thickness of the electrophysiological layer was always greater than the thickness of stratum pyramidale measured in Nissl stain. In 15 tracks in CA1 the electrophysiological layer was from 177 to $565 \mu \mathrm{m}$ thick $(\overline{\mathrm{X}}=353 \mu \mathrm{m}, \sigma=121$ $\mu \mathrm{m})$. In Nissl stain, the stratum pyramidale of CA1 was up to $83 \mu \mathrm{m}$ thick. In seven tracks in CA3 the electrophysiological layer was from 212 to 425 $\mu \mathrm{m}$ thick. $(\overline{\mathrm{X}}=291 \mu \mathrm{m}, \sigma=74 \mu \mathrm{m})$. Stratum pyramidale of CA3 was up to $117 \mu \mathrm{m}$ thick in Nissl stains. In all the tracks the largest amplitude action potentials were seen in the middle of the electrophysiological layer.

There was a layer of nontheta cells corresponding to stratum granulosum also (Fig. 2), but the borders of this layer are not always as clear as in Ammon's horn. Prussian blue marks were made in two tracks through this layer where complex spike cells were being recorded. Both marks were in stratum granulosum. Complex spike cells were also seen in the hilus.

All but four of the cells classified as "other" were so classified because poor isolation or small amplitude made it impossible to determine duration of the action potential or to estimate firing rates. Three of these "other" cells fired rapidly $(20-60 / \mathrm{sec})$ and did not have complex spikes, but they were not theta cells. These three cells were all in the hilus of fascia dentata. There was one neuron in stratum moleculare of CA1 which fired at $20-40 / \mathrm{sec}$, but which turned off during a slow wave theta rhythm (an antitheta cell). [We have seen another similar antitheta cell in an unpublished study. Best (personal communication) has also found rare nontheta cells in the vicinity of hippocampal fissure.] We have looked for, but have not been able to discover any other categories hidden within the "other" cell category.

Thus, out of 942 nontheta cells of greater than $80 \mu \mathrm{V}$ only one was not in the hilus of fascia dentata or in a layer that overlapped stratum granulosum or stratum pyramidale.

Theta cell distribution is given in Figs. 3 and 4. In fascia dentata most theta cells were in the hilus, and none were seen in stratum moleculare. [One was seen in stratum moleculare in an earlier study (5).] None were seen in the ventral part of the hilus of fascia dentata. In CA1 most theta 


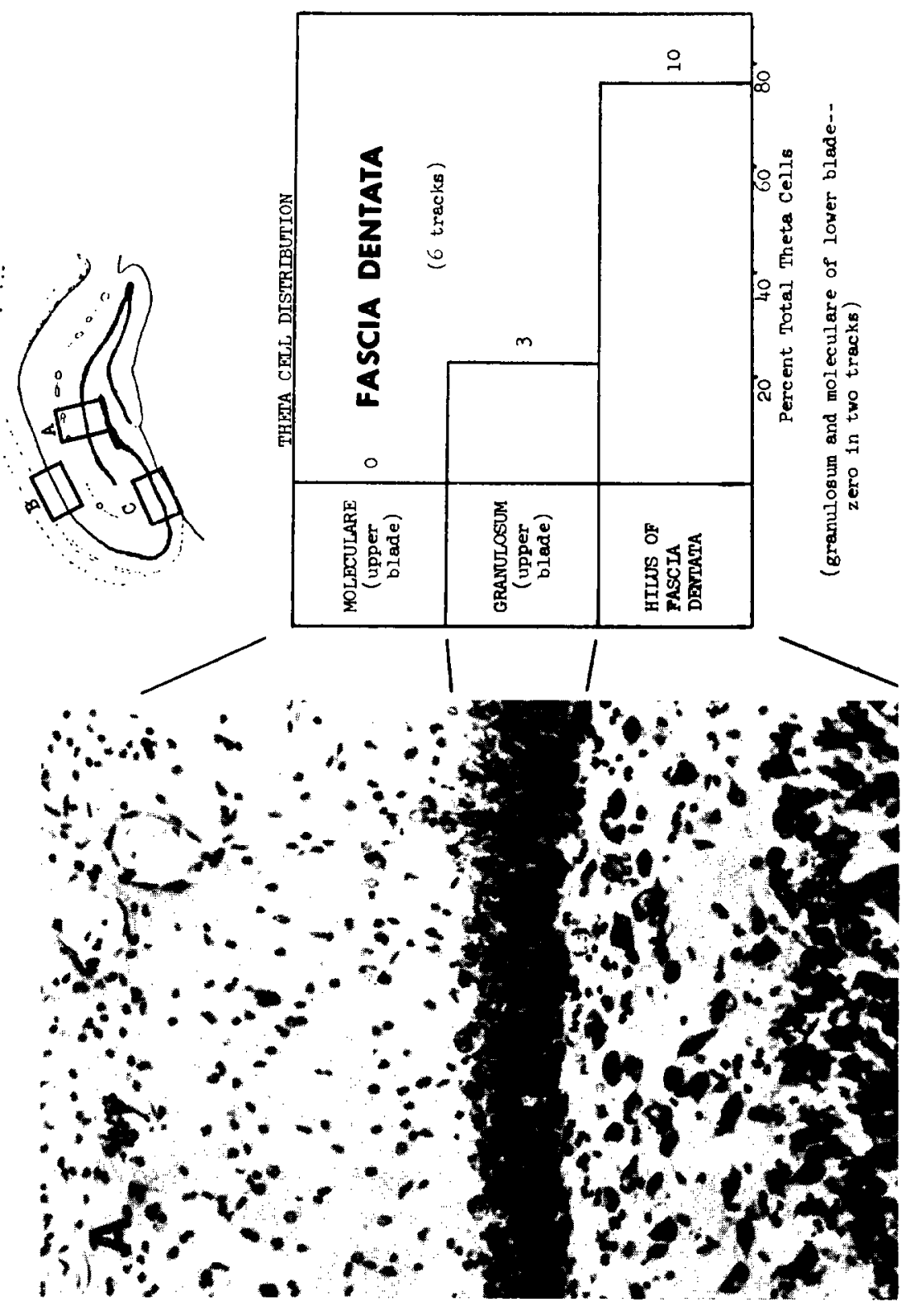




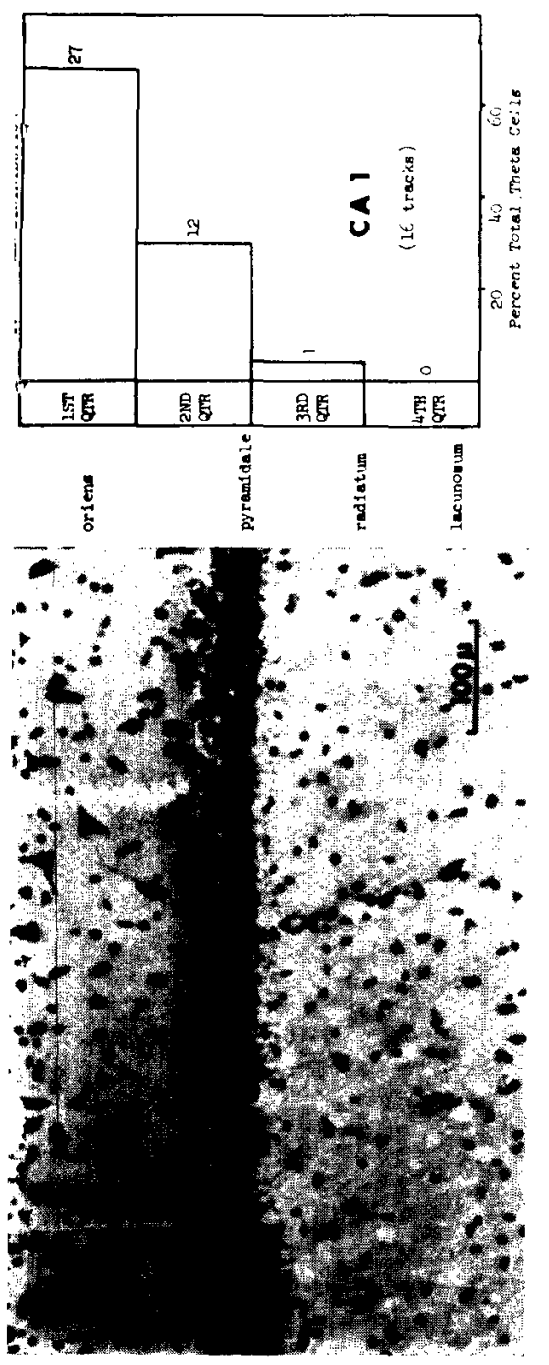

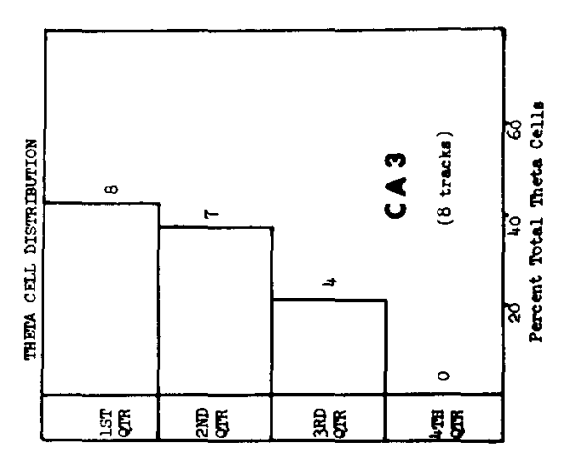

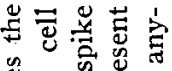

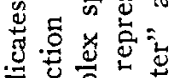
晒

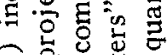
क 我导焉导

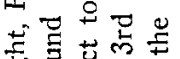

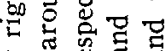
政

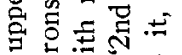
430

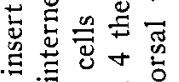

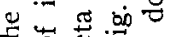

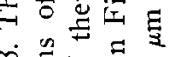

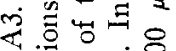
U

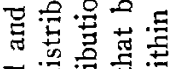
구을 U

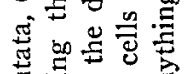

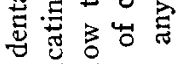

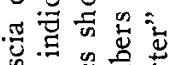

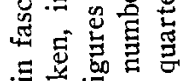

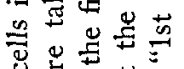

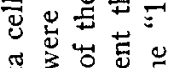
过 3

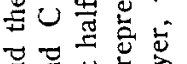

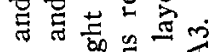

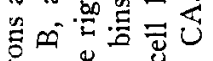

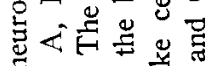

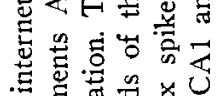

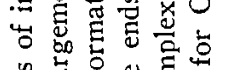

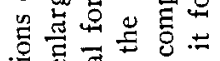

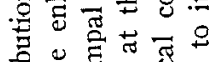
है

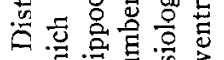
$\checkmark$ 要寻 छ 总岁声莺令

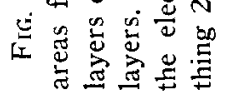




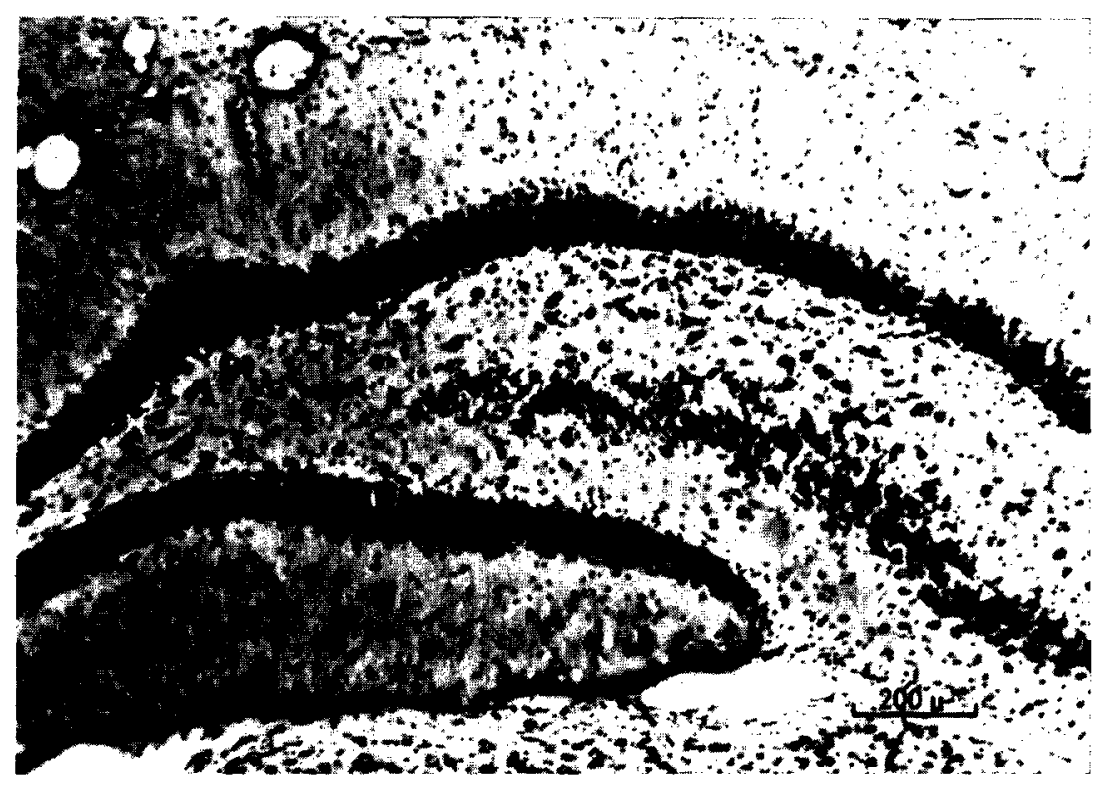

FIG. 5. Photograph of Nissl stained frontal section of the fascia dentata areas of rat hippocampal formation. Note the lack of neurons in the molecular layer and on the ventral side of CA3-4, inside the hilus.

cells were in stratum oriens, and almost none in apical dendritic layers. In CA3, most theta cells were in apical dendritic layers and none in stratum oriens. Some theta cells are in stratum pyramidale and stratum granulosum. The photomicrographs in Figs. 3-5 show that there are indeed very few neurons in apical dendritic layers of CA1, basal dendritic layers of CA3, and the ventral part of the hilus of fascia dentata. Some of the ventral part of the hilus of fascia dentata is stratum oriens of CA3, and the rest is in continuity with stratum oriens of CA3. One track was made all the way through dorsal hippocampus in which only theta cells were recorded. Histology showed this tract to be located lateral to the curve of Ammon's horn, remaining in stratum oriens of CA3a and never entering stratum pyramidale. (This track is not included in the data of Fig. 4 since the track did not cross all strata.) The paucity of neurons in stratum oriens of CA3 is more striking in CA3b and $\mathrm{c}$ than in CA3a.

Cell counts were performed by drawing two parallel lines on the cover slip of Nissl stained sections ( 8 or $40 \mu \mathrm{m}$ thick), measuring the distance between the lines, then counting the numbers of neurons in the layers between the two lines and averaging numbers/unit length for a given section thickness. Sections $8 \mu \mathrm{m}$ thick were used so that the dense pyramidal and granule cell layers could be counted. The more satisfactory $40 \mu \mathrm{m}$ sections were used to count neurons in other strata. No correction 
was made for section thickness and neuron size. In the $8 \mu \mathrm{m}$ sections, only the cells in which nucleoli could be identified were counted. These counts cannot be considered "quantititative," but only "semiquantitative." Table 2 gives the numbers of neurons which one would expect to observe based on these counts and the number of neurons actually observed. (See table legend for details of the calculation.) The nature of the data (cf. Discussion) does not make it proper to consider "agreement" between the expected and observed numbers of cells. There is, however, a correspondence.

\section{DISCUSSION}

The significant difference demonstrated here between the spike height distributions of theta cells and complex spike cells is one more bit of evidence that these are indeed two distinct groups of cells. Because of the

TABI,E 2

Expected and Observed Numbers of Cells in the Various LAYERS OF Hippocampal Formation ${ }^{a}$

\begin{tabular}{|c|c|c|}
\hline Layer & $\begin{array}{l}\text { Expected no. } \\
\text { of cells } \\
(20-50 \mu \mathrm{m} \mathrm{r} . \\
\text { "tracks") }\end{array}$ & $\begin{array}{l}\text { Average no. } \\
\text { of cells observed } \\
\text { (per track) }\end{array}$ \\
\hline \multicolumn{3}{|l|}{ CA1 } \\
\hline $\begin{array}{l}\text { Oriens } \\
\text { Pyramidale } \\
\text { Apical dend. layers }\end{array}$ & $\begin{array}{c}0.8-5.1 \\
40-240 \\
0.4-2.2\end{array}$ & $\begin{array}{c}1.1-1.6 \\
\text { (roughly) } 36 \\
<0.1\end{array}$ \\
\hline \multicolumn{3}{|l|}{$\mathrm{CA} 3$} \\
\hline $\begin{array}{l}\text { Apical dend. layers } \\
\text { Pyramidale } \\
\text { Oriens }\end{array}$ & $\begin{array}{c}1.4-8.7 \\
20-100 \\
0.3-1.8\end{array}$ & $\begin{array}{c}0.8-1.4 \\
\text { (roughly) } \\
0^{b}\end{array}$ \\
\hline \multicolumn{3}{|l|}{ F.D. } \\
\hline $\begin{array}{l}\text { Moleculare } \\
\text { Granulosum }\end{array}$ & $\begin{array}{c}0.2-1.2 \\
100-500\end{array}$ & $\begin{array}{c}0^{b} \\
-\end{array}$ \\
\hline
\end{tabular}

a Neuron counts were performed (see text) and approximate densities calculated. The numbers of neurons one would expect to lie within cylindrical "cores" of tissue of 20 and $50 \mu \mathrm{m}$ radii were calculated, yielding an approximation for the expected range of numbers of neurons one could record from (assuming a 20-50 $\mu \mathrm{m}$ maximum recording distance). These ranges are displayed in the left column of figures. The right hand column shows ranges (depending on interpretation of exact cell location) of actual numbers of units recorded from in the various layers (see Discussion).

${ }^{b}$ Theta cells have been recorded from in these sites in other studies. 
large overlap in the spike heights of the two groups this difference is much weaker than many of the others demonstrated, where little or no overlap exists (10).

The cell counts (Table 1) are obviously approximate. First, theta cells fire at a much faster rate than do complex spike cells and are therefore easier to pick out of background noise. They can be heard as a buzzing sound at a frequency of about $6-10 \mathrm{cycle} / \mathrm{sec}$, at a lower amplitude than they can be seen on the screen of the oscilloscope. Since complex spike cells fire at such a slow rate and often only during such specific behaviors it is very possible that in $5 \mathrm{~min}$ of observation the rat never engaged in the particular behavior that was associated with firing of some of the complex spike cells that were within recording distance. Since the dendritic arborizations in projection cells and interneurons are so different it is probable that the distance from which it is possible to record from the two types might differ considerably. When recording from all units, only those action potentials which differed in amplitude by at least $20 \%$ were counted as distinct units. When the electrode was located in the complex spike cell layer of CA1 or CA3, many units were recorded from at the same time, and it is possible that many of the units counted as only one cell were, in fact, more than one. This factor is not a problem with the counting of theta cells, since they are almost always very well isolated from other theta cells. It is easy to tell the difference between a theta cell and a complex spike cell (firing at the same site and of the same amplitude) as observed on the oscilloscope. In penetrating the layers of the hippocampal formation at $35.3 \mu \mathrm{m}$ intervals, it may have been possible to record from a particular cell at more than one site, so that a single cell would appear at one amplitude at one location, an another amplitude at another. It was possible to record from well isolated theta cells over a range of slightly more than $70 \mu \mathrm{m}$ in the vertical dimension. A comparable test is not possible with complex spike cells because of lack of isolation. On the other hand, a single advance of $35.3 \mu \mathrm{m}$ might pass all the way through the region in which a neuron could be recorded, and the neuron might not be noted at all. All of these problems are worse when recording in fascia dentata. It seems likely that the proportion of theta cells is overestimated. These estimates are nevertheless better than those reported previously (10).

The electrophysiological layer of nontheta cells is much thicker than the stratum pyramidale. Even if we assume that we can record action potentials $50 \mu \mathrm{m}$ away from the cell body, we cannot explain the discrepancy. Perhaps there is more tissue drag in the cell body layer than in dendritic layers. It seems more likely that we can record action potentials from pyramidal cells $50-200 \mu \mathrm{m}$ out in the dendrites. The data are not good enough to decide if this extra width is largely on the side of the apical 
dendrites or basal dendrites or equally distributed. For the main purposes of this study, though, it is clear that the electrophysiological layer includes all of stratum pyramidale and stratum granulosum.

There are a few pyramidal cell bodies outside of stratum pyramidale (6). Conversely, some interneurons have cell bodies in stratum pyramidale and stratum granulosum. We cannot identify interneurons in a Nissl stain. However, almost all neuron cell bodies well outside of stratım pyramidale, stratum granulosum, or CA4 are interneurons. Almost all cell bodies in stratum pyramidalc or stratum granulosum arc projection cells. With only one exception, all cells seen well outside of stratum pyramidale, stratum granulosum, or CA4 were theta cells. Therefore, the class of theta cells and the class of interneurons must have a very large overlap. (We must not assume that all interneurons generate action potentials.) With one exception out of 942 , all nontheta cells were seen in the regions of cell bodies of projection cells. Almost all cells in these regions are nontheta cells. Therefore, the class of nontheta cells and the class of projection cells must have a very large overlap. Perhaps theta cells and interneurons are identical, and perhaps nontheta cells and projection cells are identical.

We know of no data which are in conflict with these conclusions. Neurons with certain electrophysiological characteristics have been suggested to be interneurons (1-4). These suggestions are discussed elsewhere (10, pp. 515-516). Andersen, Gross, Lomo, and Sveen (3) estimated that interneurons are about $0.5 \%$ of the neurons in Ammon's horn. They did not make it clear how the counts were made. Considering the errors in any cell counting method and the errors in the neuron counts of this study, these two estimates, while not in agreement, may not be inconsistent.

At least some interneurons inhibit some projection cells $(1,2)$. The behavioral correlates of theta cells are in many ways the opposite of that of many nontheta cells (this is discussed in reference 10 , p. 514).

Shaban (12) studied unanesthetized curarized rabbits with intracellular and extracellular recording and described two types of neurons in CA1 and CA2 in dorsal hippocampus. His type A neurons ( $71 \%$ of the total) were slow firing (rate unspecified), were in the layer of cell bodies of pyramidal cells, and ceased firing and had IPSP's after sciatic stimulation. His type $\mathrm{B}$ neurons were rapid firing $(10-30 / \mathrm{sec})$, were superficial to type $\mathrm{A}$, and increased their rate of firing after sciatic stimulation. Type A's may be our nontheta cells, and type B may be theta cells.

The behavioral correlates and firing repertoires of neurons in medial septal nucleus of unrestrained rats have been recently studied in this laboratory (11). There are at least two types of neurons in medial septal nucleus - theta cells and tight group cells. Many of these septal theta cells 
are exactly like theta cells in Ammon's horn and fascia dentata, and all are similar. The tight group cells fire in specific consummatory behaviors and fire a group of action potentials with interspike intervals similar to those seen during a complex spike. These groups occur no more often than three per second. Thus, tight group cells have some characteristics in common with complex spike cells. Neurons in medial septal nucleus of rat project to stratum oriens and suprapyramidal strata of $\mathrm{CA} 3$ and to the polymorph and "supragranular region" of fascia dentata (7). (The "supragranular region" (7) is the outermost part of stratum granulosum and innermost part of stratum moleculare.) On the basis of these data and the differential localization of interneurons shown in this paper, it is suggested elsewhere (11) that septal theta cells project primarily to theta cells in suprapyramidal strata of $\mathrm{CA} 3$ and the polymorph layer of fascia dentata, and that tight group cells project primarily to dendrites of projection cells in stratum oriens of CA3 and in the "supragranular region" of fascia dentata.

\section{REFERENCES}

1. Andersen, P., J. C. Eccles, and Y. Loyning. 1964a. Location of postsynaptic inhibitory synapses on hippocampal pyramids. J. Neurophysiol. 27 : 592-607.

2. Andersen, P., J. C. Eccles, and Y. Loyning. 1946b. Pathway of postsynaptic inhibition in the hippocampus. J. Neurophysiol. $27: 608-619$.

3. Andersen, P., G. N. Gross, T. Lomo, and O. Sveen. 1969. Participation of inhibitory and excitatory interneurons in the control of hippocampal cortical output, pp. 415-465. In "The Interneuron." M. A. B. Brazier [Ed.]. University of California Press, Berkeley and Los Angeles.

4. Dichter, M., and W. A. Spencer, 1969. Penicillin-induced interictal discharges from the cat hippocampus. II. Mechanisms underlying origin and restriction. J. Neurophysiol. 32 : 663-687.

5. Feder, R., and J. B. Ranck, JR. 1973. Studies on single neurons in dorsal hippocampal formation and septum in unrestrained rats. Part II. Hippocampal slow waves and theta cell firing during bar pressing and other behaviors. Exp. Neurol. $41: 532-555$.

6. LoREnte DE Nó, R. 1934. Studies on the structure of the cerebral cortex. II. Continuation of the study of the Ammonic system. J. Psychol. Neurol. 46: 113-177.

7. Mosko, S.. G. Lynch, and C. W. Cotman. 1973. The distribution of septal projections to hippocampus of the rat. J. Comp. Neurol. 152: 163-174.

8. Olmstean, C. F., and P. J. Best. 1974. Patterns of dorsal hippocampal unit activity. Society for Neuroscience, Abstract \#507.

9. RANCK, J. B., JR., 1973a. A moveable microelectrode for recording from single neurons in unrestrained rats, pp. 76-79. In "Brain Unit Activity during Behavior." M. I. Phillips [Ed.]. University of Iowa Press, Iowa City.

10. Ranck, J. B., JR. 1973b. Studies on single neurons in dorsal hippocampal forma- 
tion and septum in unrestrained rats. Part I. Behavioral correlates and firing repertoires. Exp. Neurol. $41: 461-531$.

11. RANCK, J. B., JR. 1975. Behavioral correlates and firing repertoires of neurons in septal nuclei in unrestrained rats. In "The Septal Nuclei." J. DeFrance [Ed.]. Wayne State University Press. (In press.)

12. Shaban, V. M. 1969. Temporal relationships between hippocampal evoked potential and unit activity. Neirofiziolsgiva 1: 285-292. (Translation published in Neuroscience Translations \#14, pp. 77-84.) 